\title{
Komlos, John: Foundations of real world economics: what every economics student needs to know
}

\section{2nd Edition, Routledge, New York and London, xiii + 292 pp $£ 29.99$ (Paperback)}

\section{Michael Braulke ${ }^{1}$}

Published online: 31 July 2019

(c) Springer-Verlag GmbH Austria, part of Springer Nature 2019

This text appears to rest on a misunderstanding. It is my impression that Komlos confuses his "mainstream" economists with true believers in perfect markets. And so he bashes them from front to end for being blind to imperfections, abuse of market power etc. It is a while ago that I complained to Reinhard Selten at my Ph.D. party that economic theory would offer so little reliable knowledge. His answer was: "You're right if you refer to important issues such as the business cycle or unemployment. But don't underestimate what we know about the price mechanism". And indeed, that is much more than the properties of prices in perfect markets. The regular economics student is exposed first, of course, to the plain aspects of perfect competition, but the more demanding topics such as creative destruction (Schumpeter), public goods (Samuelson), asymmetric information (Akerlof), entitlements (Sen), natural monopolies and so on follow soon.

I welcome any serious critique of economics. But I don't accept that Komlos blames economics and economists for what is in reality outrageous behaviour, obscene greed, plain incompetence, or ethical failure of CEOs, investors, and politicians. His angry book is full of examples and references.

Publisher's Note Springer Nature remains neutral with regard to jurisdictional claims in published maps and institutional affiliations.

Michael Braulke

michael.braulke@uni-osnabrueck.de

1 Universität Osnabrück, Osnabrück, Germany 